\title{
Pemanfaatan Media Microsoft Power Point dalam Pembelajaran Kemahiran Berbahasa Arab pada Era Digital
}

\author{
Mabruri $^{1}$, Hamzah $^{2}$ \\ ${ }^{1}$ STIT YAPIMA Muara Bungo, Jambi \\ 1 e-mail: mabrurilana@yahoo.co.id \\ ${ }^{2}$ Insitut Agama Islam DDI Polewali Mandar, Sulawesi Barat \\ 2 e-mail: hamzah87_aziz@ymail.com
}

\begin{abstract}
Life in the Digital Age is automatically required by someone not to be out of date with a device or device such as a computer or laptop. Data and information even the basic needs of a student can be said to have been stored in a system called a digital system. Everything is available in one system that can and is freely accessed by anyone. as a teacher in utilizing sophisticated tools in this digital age, it is demanded to adjust and apply in the form of a learning as the medium. So one of the things that can be used by a teacher is to use Microsoft Power Point program as a medium in innovating a learning. This paper aims to develop an Arabic learning media by using Microsoft Power Point program as a medium in learning Arabic proficiency.
\end{abstract}

Keywords: Learning Media, Microsoft Power Point, Arabic Language Proficiency Learning

\begin{abstract}
Abstrak
Hidup di Era Digital secara otomatis seseorang dituntut untuk tidak ketinggalan zaman dengan alat atau perangkat semacam komputer atau laptop. Data dan informasi bahkan kebutuhan pokok seorang siswa bisa dikata sudah tersimpan dalam sebuah sistem yang disebut sebagai sistem digital. Semuanya sudah tersedia dalam satu sistem yang bisa dan bebas diakses oleh siapa saja. sebagai seorang guru dalam memanfaatkan alat canggih di era digital ini, dituntut untuk menyesuaikan dan menerapkan dalam bentuk sebuah pembelajaran sebagai mediumnya. Maka salah satu di antara yang bisa digunakan oleh seorang guru adalah dengan memanfaatkan program microsoft power point sebagai medium dalam menginovasi sebuah pembelajaran. Tulisan ini bertujuan untuk mengembangkan sebuah media pembelajaran bahasa Arab dengan menggunakan program microsoft power point sebagai media dalam pembelajaran kemahairan bahasa Arab.
\end{abstract}

Kata Kunci: Media Pembelajaran, Microsoft Power Point, Pembelajaran Kemahiran Berbahasa Arab 


\section{Pendahuluan}

Dalam aktivitas pembelajaran banyak hal yang bersifat kompleks ditemukan oleh guru, disebabkan latar belakang, kemampuan dan sifat peserta didik yang bervariasi. Untuk mengajar setidaknya guru dituntut untuk memutar otak agar mengajar tidak dengan cara tunggal, melainkan dengan cara bervariasi sehingga kegiatan pembelajaran menjadi efektif dan efisien. Dalam hal tersebut, Guru harus menguasai beraneka ragam metode dan strategi serta paham betul bagaimana cara mempraktekkannya secara fleksibel sehingga tujuan pembelajaran dapat tercapai sesuai dengan kurikulum yang telah disusun.

Proses pembelajaran merupakan proses komunikasi dan berlangsung dalam suatu sistem maka media pembelajaran menempati posisi yang cukup penting sebagai salah satu komponen sistem pembelajaran. Tanpa media komunikasi tidak akan terjadi dan proses pembelajaran sebagai proses komunikasi juga tidak akan berlangsung secara optimal. Media pembelajaran merupakan sarana perantara yang digunakan sebagai alat dan bahan kegiatan dalam proses pembelajaran. ${ }^{1}$

Disaat ini berbagai macam media pembelajaran yang dapat digunakan oleh guru, mulai dari media yang sederhana sampai media yang berteknologi tinggi. Disaat banyak alternatif media yang dapat digunakan, sungguh naif sekali jika seorang guru tidak menggunakan dan memiliki kemampuan untuk memanfaatkan media pembelajaran. Karena media pembelajaran memiliki kontribusi yang cukup besar dalam proses belajar mengajar pada siswa, Hamalik (1986) dalam Azhar Arsyad mengemukakan bahwa :

"Pemakaian media pembelajaran dalam proses belajar mengajar dapat membangkitkan keinginan dan minat yang baru, membangkitkan motivasi dan rangsangan kegiatan belajar, dan bahkan membawa pengaruh pengaruh psikologis terhadap siswa. Penggunaan media pembelajaran pada tahap orientasi pembelajaran akan sangat membantu keefektifan proses pembelajaran dan penyampaian pesan dan isi pelajaran pada saat itu. ,2

Memasuki era modern dan serba canggih ini, Teknologi Informasi dan Komunikasi (TIK) disaat ini begitu sangat dirasakan kebutuhan dan pentingnya penggunaan TIK dalam proses pembelajaran. Banyak pilihan menu dan program yang bisa digunakan dalam teknologi tersebut, hanya saja guru tinggal menyesuaikan dan mencocokkan menu dan program mana dari media teknologi yang sangat berperan dalam membantu kegiatan siswa belajar.

Rusman mengungkapkan bahwa melalui TIK kita dapat meningkatkan mutu pendidikan, yaitu dengan cara membuka lebar-lebar terhadap akses ilmu pengetahuan dan teknologi informasi dalam rangka penyelenggaraan pendidikan yang berkualitas. Terutama penerapan high tech dan high touch approach. ${ }^{3}$

Komputer merupakan hasil karya teknologi canggih yang memiliki berbagai aplikasi, salah satunya terdapat aplikasi Power Point, yang mana aplikasi ini termasuk ke dalam pembelajaran berbasis multimedia presentasi. Media ini cukup dapat dihandalkan karna

\footnotetext{
${ }^{1}$ Daryanto, Media Pembelajaran, (Bandung: PT. Sarana Tutorial Nurani Sejahtera, 2012), h. 4.

2 Azhar Arsyad, Media Pembelajaran, (Jakarta : PT RajaGrafindo Persada, 2010), h. 15.

3 Kurniawan Rusman dan Riyana, (Pembelajaran Berbasis Teknologi Informasi dan Komunikasi: Mengembangkan Profesionalitas Guru, (Jakarta: PT. Raja Grafindo Persada, 2012), h. 5.
} 
menggunakan multimedia projector yang memiliki jangkauan pancar cukup besar. Media ini dapat menggabungkan semua unsur media seperti teks, video, animasi, image, grafik, dan audio sehingga menjadi satu kesatuan materi.

Hasil karya teknologi berupa Power Point ini diharapkan bisa membantu dan memberikan manfaat bagi semua pelajaran, khususnya Pelajaran bahasa arab. Pembelajaran Bahasa Arab merupakan satu bagian dari kegiatan pembelajaran baik secara formal atau pun informal. Kegiatan berbahasa arab sendiri merupakan satu bagian dari kehidupan dunia internasional, kegiatan tersebut bersifat reseptif dan produktif. Kedua kegiatan bahasa arab ini saling melengkapi dalam keseluruhan aktivitas komunikasi. Kegiatan bahasa yang bersifat reseptif meliputi membaca dan menyimak, sedangkan kegiatan berbahasa yang bersifat produktif meliputi berbicara dan menulis.

Berkaitan dengan penggunaan PowerPoint sebagai media pembelajaran, pembelajaran bahasa arab juga dapat dipraktekkan dengan menggunakan power point, dalam hal ini dapat digunakan dalam pembelajaran kemahiran berbahasa. Dengan demikian, penulis akan membahas "Penggunaan Power Point dalam Pembelajaran Kemahiran Berbahasa Arab".

\section{Tinjauan Umum}

\section{- Power Point}

Power Point adalah salah satu teknologi multimedia. Salah satu kegunaan terpenting dari teknologi ini adalah memudahkan instruktur menggabungkan berbagai multimedia ke dalam pengajaran dan instruksi mereka. ${ }^{4}$

Suhendi mengemukakan Power Point merupakan program aplikasi kantor bertipe slide show (lembar kerja yang merupakan kaca objek yang menampilkan objek bergantian) yang digunakan untuk mempresentasikan konsep dan argumen yang ingin ditunjukkan pada orang lain dengan tampilan grafis yang menarik. ${ }^{5}$

Dari definisi diatas dapat dipahami bahwa power point merupakan aplikasi presentasi yang memberikan fasilitas menu pilihan untuk memudahkan pelaku dalam mendesain atau merancang apa yang akan dipresentasikan, sehingga presentasi yang disampaikan akan terlihat menarik. Dalam hal ini, power point dapat digunakan dalam pembelajaran untuk merangsang peserta didik dalam belajar.

Strategi pembelajaran yang tepat dalam menggunakan media Power Point akan memberikan penekanan kepada pengembangan aspek kognitif, afektif, dan psikomotorik secara seimbang, sehingga pembelajaran menggunakan media power point ini dianggap lebih bermakna.

Dan sangat penting diingat oleh para guru dalam menggunakan power point jangan sampai guru penuh semangat mempresentasikan materi pelajaran justru siswa menjadi audien yang pasif karna akan mempengaruhi kreativitas dan imajinasi anak menjadi tidak berkembang secara maksimal.

4 Kheira Altaher Musa Alkash dan Zamzam Emhemmad Mari Al-Dersi, "Advantages of Using PowerPoint Presentation in EFL Classroom \& the Status of its Use in Sebha University", International Journal of English Language \& Translation Studies, Vol. 1, Issue. 1, Edition, April-June 2013, h. 6.

5 Edi Suhendi, Membuat Presentasi Cantik dengan Microsoft Power Point 2007 untuk Pemula, (Bandung: Yrama Widya , 2009), h. 1. 


\section{- Pembelajaran Kemahiran Berbahasa Arab}

Pembelajaran adalah proses interaksi peserta didik dengan pendidik dan sumber belajar pada suatu lingkungan belajar. ${ }^{6}$ Sedangkan kemahiran berbahasa arab dalam dunia pembelajaran bahasa arab merupakan suatu kemampuan-kemampuan atau ketrampilanketrampilan yang harus dikuasai untuk membantu dan menunjang pembelajar dalam menguasai dan menggunakan bahasa Arab.

Pada umumya, semua pakar pembelajaran bahasa sepakat bahwa keterampilan dan kemahiran berbahasa Arab tersebut terbagi menjadi empat. Diantaranya adalah keterampilan menyimak (maharah al-istima'), keterampilan berbicara (maharah al-kalam), keterampilan membaca (maharah al-qira'ah) dan keterampilan menulis (maharah al-kitabah). ${ }^{7}$

Dengan demikian pembelajaran kemahiran berbahasa arab terfokus kepada pembelajaran empat aspek dari kemahiran :

1. Pembelajaran Istima'; adalah proses atau usaha menyimak agar mampu mengenali, mengidentifikasi, memperoleh informasi dan data, memberikan interpretasi, memahami makna, menyimpulkan makna, merespon, mengapresiasi, mengkritisi, dan menilai lambang-lambang bunyi bahasa lisan melalui objek kajian yang disimak.

2. Pembelajaran Kalam; adalah proses atau usaha berbicara agar mampu menggerakkan lisan dalam bertutur kata sebagai upaya berkomunikasi, mengekspresikan, menyatakan, menyampaikan, menyebutkan, mengungkapkan dan membahasakan ide pikiran, gagasan, pendapat, pesan dan kesan perasaan.

3. Pembelajaran Qiraah; adalah proses atau usaha membaca agar mampu mengucapkan bacaan teks sesuai dengan kaidahnya serta dapat memahami, menganalisis dan menangkap makna pesan isi dari teks yang dibaca, baik dari segi teks yang tersurat maupun yang tersirat.

4. Pembelajaran Kitabah; adalah proses atau usaha menulis agar mampu menuangkan ide pikiran, gagasan, pendapat, pesan dan kesan perasaan sesuai dengan kaidahnya dalam bentuk tulisan atau catatan yang mana tulisan tersebut adalah kumpulan dari simbol-simbol, huruf-huruf dan angka-angka.

\section{Penggunaan Power Point}

\section{- Menu Pembelajaran}

Dalam materi pembelajaran kemahiran berbahasa arab penulis menggunakan buku pelajaran bahasa arab Kurikulum 2013 kelas X Madrasah Aliyah. Salah satu keuntungan dalam pembelajaran menggunakan power point adalah dapat menggabungkan semua materi didalamnya. Di bawah ini adalah contoh power point yang sudah didesain dengan empat kemahiran bahasa arab.

${ }^{6}$ Heri Rahyubi, Teori-teori Belajar dan Aplikasi Pembelajaran Motorik, (Bandung: Nusa Media, 2012), h. 6 .

7 Ulin Nuha, Metodelogi Super Efektif Pembelajaran Bahasa Arab, (Yogyakarta: Diva Press, 2012), h. 84. 


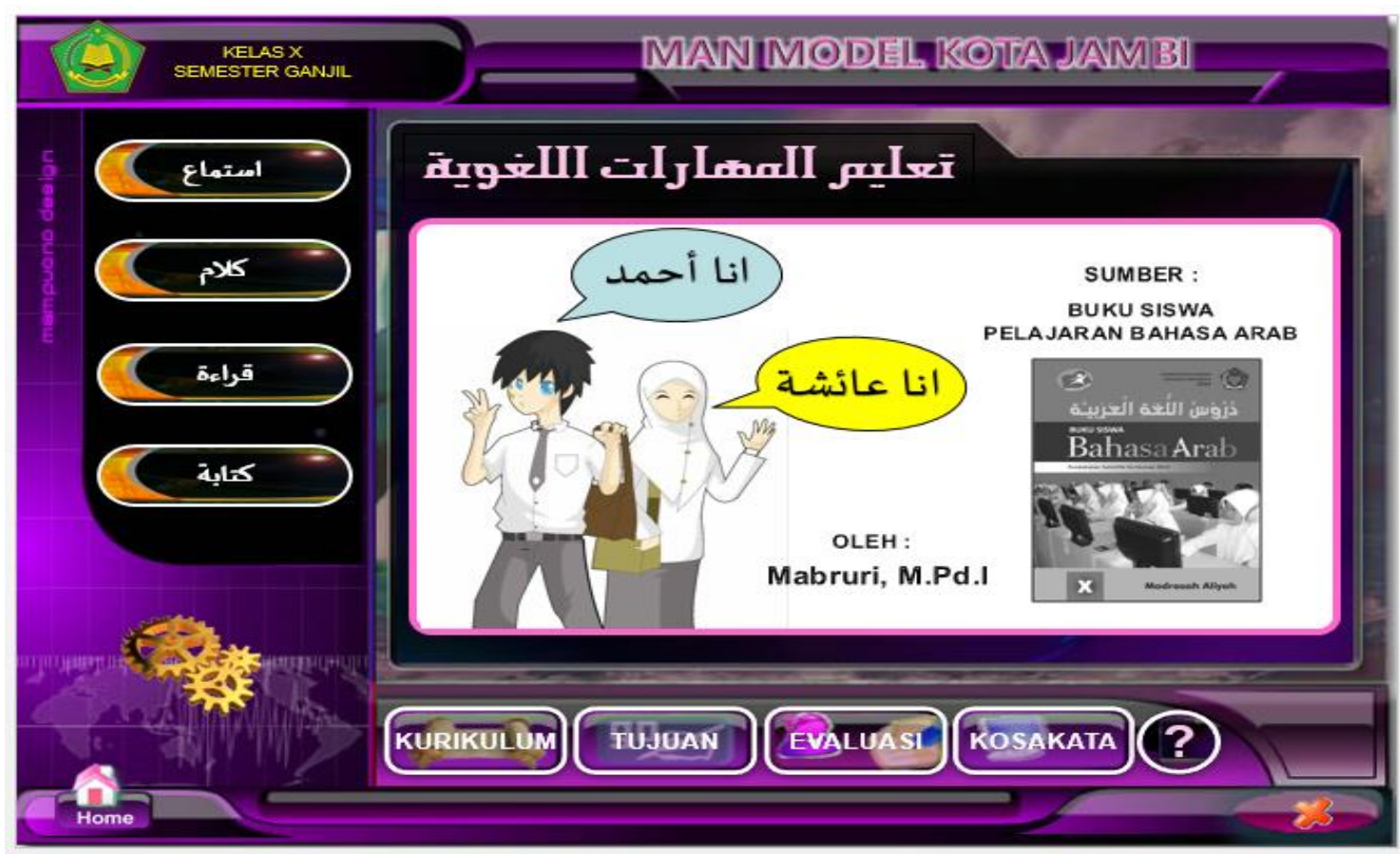

Gambar 1. Contoh tampilan menu utama pembelajaran yang sudah di desain.

Slide power point diatas telah tersedia beberapa pilihan tombol untuk digunakan dalam pembelajaran kemahiran berbahasa arab, diantaranya adalah :

a. Tombol "استماع" fungsinya adalah untuk menampilkan slide pembelajaran istima'.

b. Tombol "كلام" fungsinya adalah untuk menampilkan slide pembelajaran kalam.

c. Tombol "قراءة" fungsinya adalah untuk menampilkan slide pembelajaran qiraah.

d. Tombol "كتابة" fungsinya adalah untuk menampilkan slide pembelajaran kitabah'.

e. Tombol "kurikulum" fungsinya adalah untuk menampilkan slide kurikulum pembelajaran bahasa arab.

f. Tombol "Tujuan" fungsinya adalah untuk menampilkan slide tujuan pembelajaran bahasa arab dengan rincian masing-masing setiap kemahiran berbahasa arab.

g. Tombol "evaluasi” fungsinya adalah untuk menampilkan slide evaluasi pembelajaran bahasa arab dengan rincian masing-masing setiap kemahiran berbahasa arab.

h. Tombol "Kosakata" fungsinya adalah untuk menampilkan slide kosakata bahasa arab dalam pembelajaran kemahiran berbahasa arab.

\section{- Pembelajaran Istima'}

Pembelajaran kemahiran berbahasa arab diawali dari pembelajaran istima', maka dalam hal ini cukup mengarahkan cursor ke tombol "استماع kemudian klik tombol tersebut sehingga layar slide akan berubah seperti dibawah ini: 


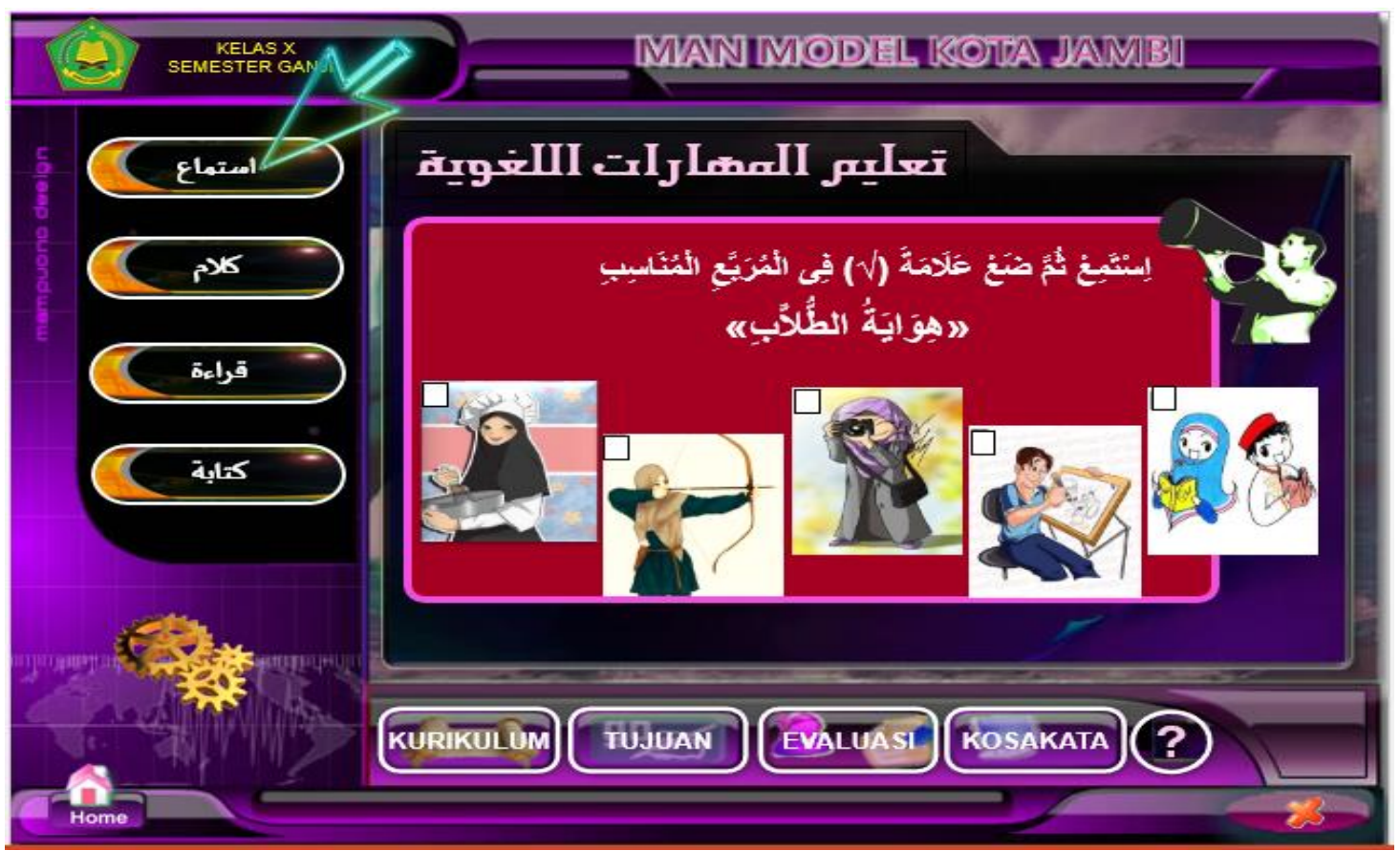

Gambar 2. Contoh tampilan menu pembelajaran istima' yang sudah di desain.

Slide diatas berubah menjadi slide pembelajaran istima', dimana sistem pembelajaran yang ditawarkan dalam pembelajaran ini adalah meminta kepada para siswa untuk mendengar audio yang berbunyi dari power point (yang sudah disediakan), kemudian para siswa memahami maksud dari bunyi kalimat dari audio itu. Dalam hal ini para siswa belajar tentang "Hobby", yang mana para siswa menyimak suara aktivitas yang dilakukan para siswa dalam suara audio. ketika salah satu dari siswa memahami aktivitas hobby (Suara dari Audio) tersebut maka ia dapat meberikan tanda $(\sqrt{ })$ pada pada pilihan gambar yang sudah disediakan dalam slide Power Point.

\section{- Pembelajaran Kalam}

Pembelajaran kalam juga dapat digunakan melalui media power point. Pilih atau arahkan cursor ke tombol "كلام untuk menampilkan pembelajaran kalam, maka slide akan berubah seperti ini : 


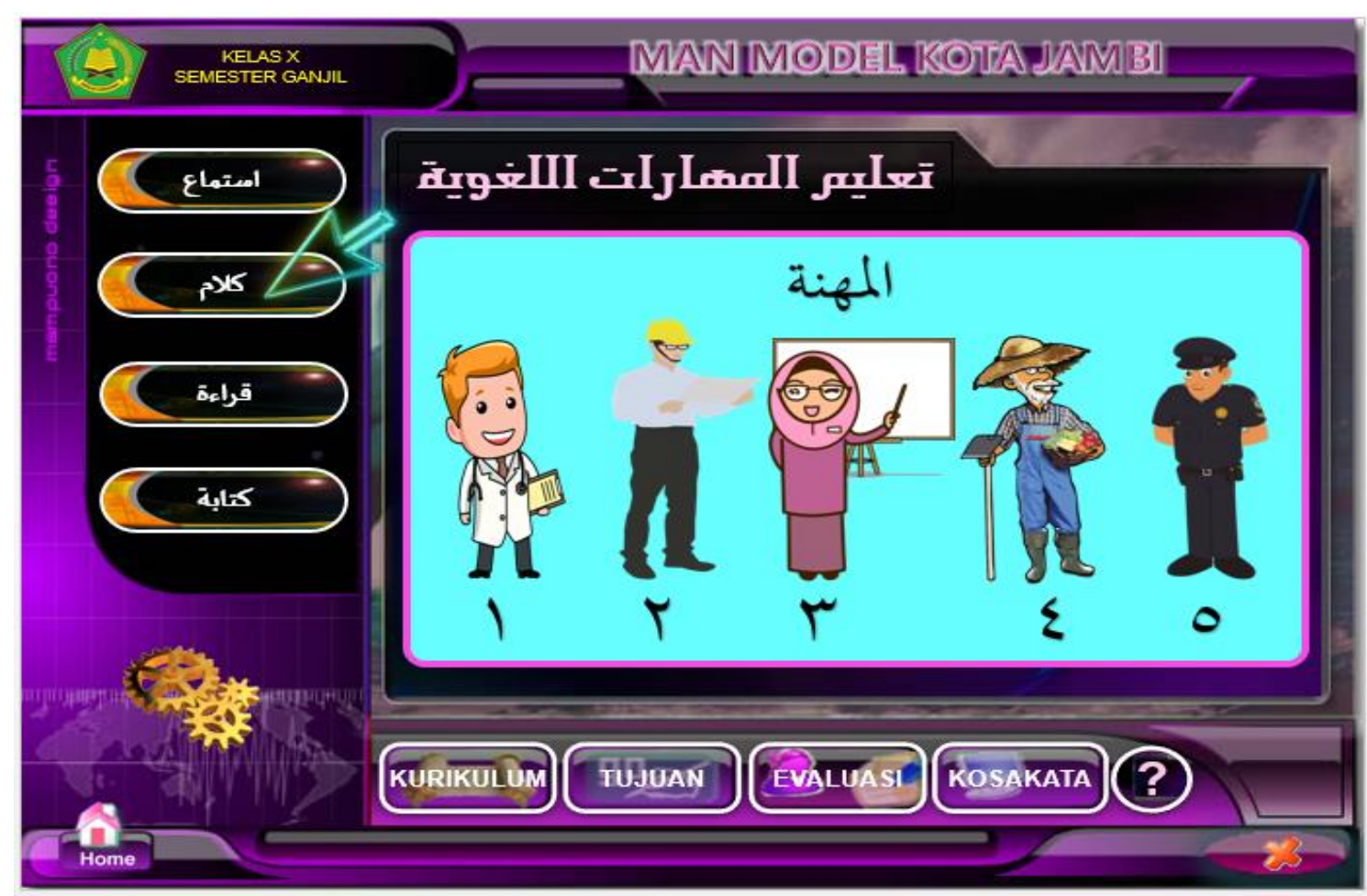

Gambar 3. Contoh tampilan menu pembelajaran kalam yang sudah di desain.

Pembelajaran kalam diatas adalah tentang Profesi, yang mana dalam slide power point tersebut sudah disediakan gambar-gambar animasi berbagai profesi. Gambar-gambar animasi diatas adalah contoh profesi yang dapat dibicarakan oleh para siswa dalam bahasa arab. Guru dapat meminta masing-masing siswa untuk mempraktekan kemahiran berbicara bahasa arab ke depan kelas dengan menceritakan macam-macam profesi dan aktivitasnya, atau guru juga bisa meminta para siswanya untuk memilih salah satu profesi yang mereka suka di dalam slide power point tersebut, kemudian dipraktekkan dalam kemahiran berbicara bahasa arab di depan kelas. Namun sebelum salah satu siswa ditunjuk ke depan untuk berbicara bahasa arab, hendaknya guru memberikan waktu persiapan kepada para siswa sekitar 5-10 menit dan guru juga sudah mempersiapkan dan menyediakan kosakatakosakata yang berkaitan dengan profesi sebagai bantuan untuk mempermudah mereka dalam menyusun kalimat.

\section{- Pembelajaran Qira'ah}

Sebagaimana yang telah dijelaskan sebelumnya, bahwa tombol "قراءة" fungsinya adalah untuk menampilkan slide pembelajaran qira'ah. Dibawah ini adalah contoh slide dalam pembelajaran qira'ah: 


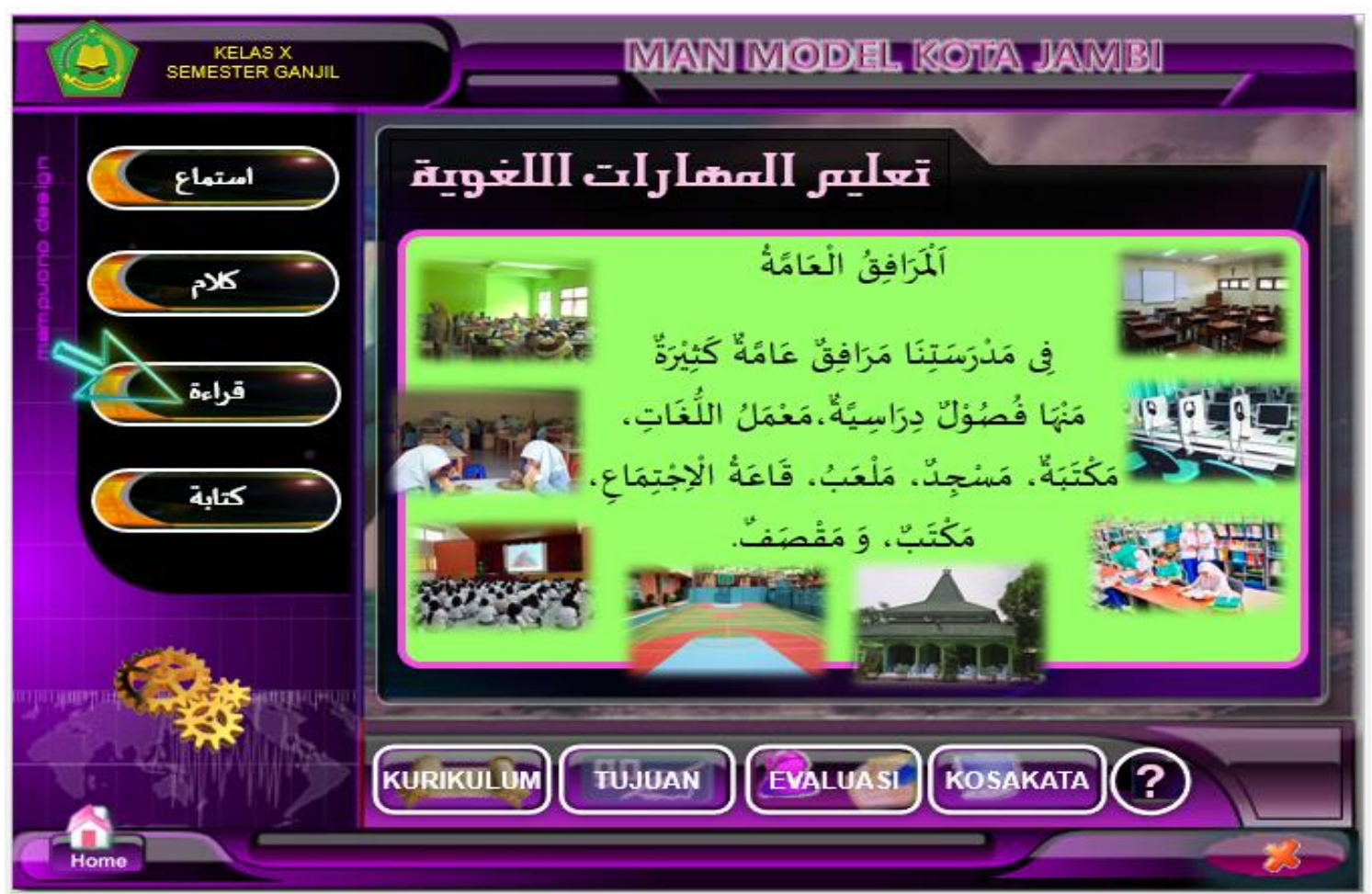

Gambar 4. Contoh tampilan menu pembelajaran qira'ah yang sudah di desain.

Slide Power Point diatas berbicara tentang "Fasilitas Umum" khususnya yang ada di dalam sekolah. Dalam pembelajaran qira'ah di atas para siswa diminta untuk membaca teks bahasa arab dengan sesuai kaidah bahasa arab, kemudian mereka diminta untuk memahami isi teks bahasa arab tersebut. Untuk memudahkan mereka dalam memahami teks bahasa arab, guru dapat menampilkan gambar-gambar (dalam slide Power Point) yang berkaitan dengan fasilitas umum sehingga dapat menegaskan pemahaman mereka terhadap makna teks yang mereka baca.

\section{- Pembelajaran Kitabah}

Setelah pembelajaran qira'ah, dilanjutkan dengan pembelajaran kitabah, yang mana pembelajaran kitabah adalah pembelajaran kemahiran yang paling akhir setelah pertemuan pembelajaran di tiga kemahiran (istima, kalam dan qira'ah) sebelumnya. Selanjutnya untuk melangkah pembelajaran kitabah maka dalam slide yang sudah ada tinggal meng-klik tombol "كتابة untuk menampilkan pembelajaran kitabah sebagaimana gambar berikut : 


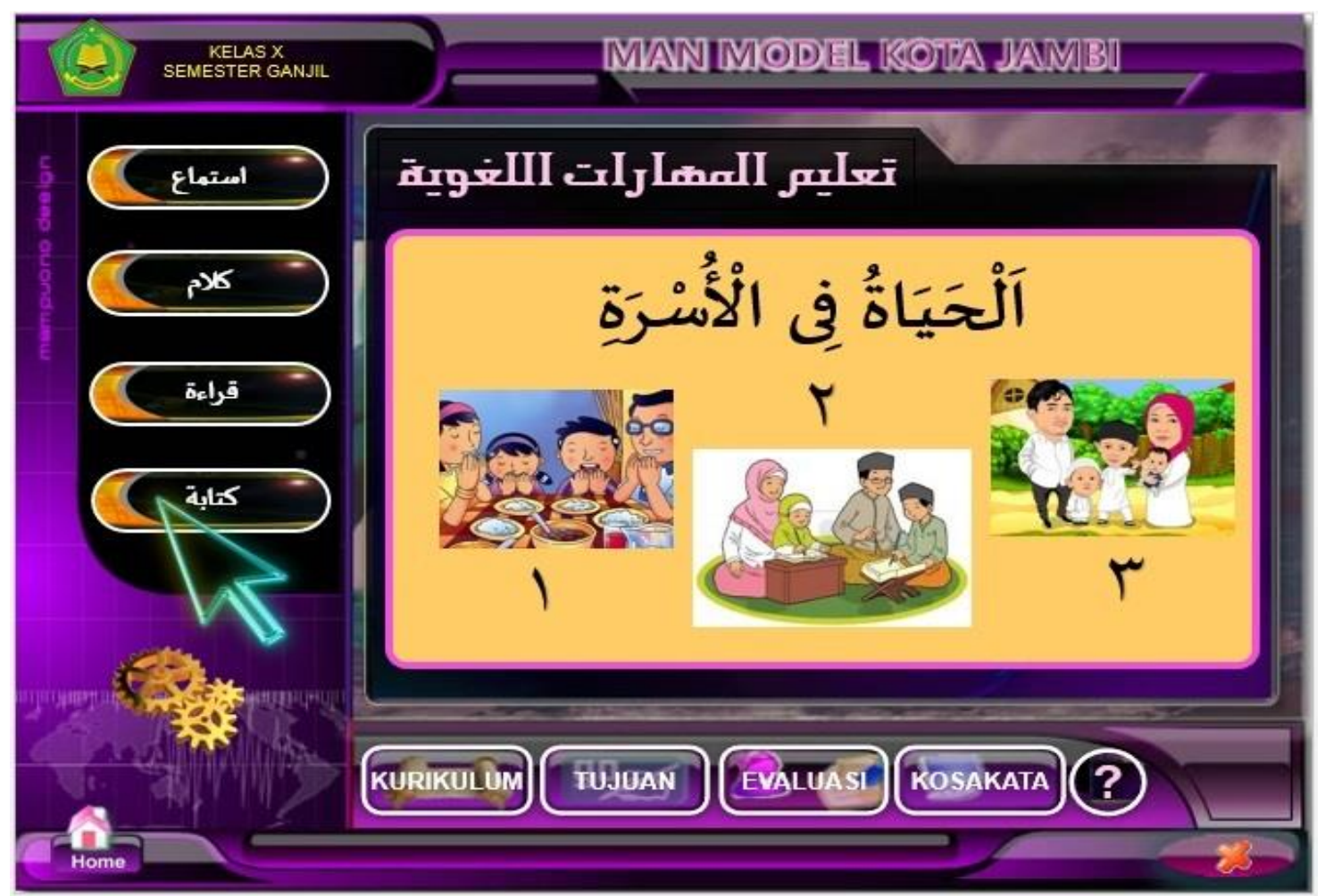

Gambar 5. Contoh tampilan menu pembelajaran kitabah yang sudah di desain.

Slide diatas menampilkan pembelajaran kitabah yang membahas "Kehidupan dalam Keluarga". Aktivitas kehidupan keluarga ditampilkan dalam tema ini mulai dari pagi hingga malam. Dalam slide diatas terdapat 3 tampilan aktivitas yang dilakukan oleh keluarga, adapun kaitannya dalam pembelajaran kitabah guru meminta siswa untuk menceritakan dan mengembangkan gambar tersebut menjadi cerita dengan beberapa paragraf tentang kegiatan keluarga di atas (seperti yang terdapat dalam slide) dalam bentuk tulisan bahasa arab, dengan seperti itu para siswa dituntut untuk mengarang dan mengembangkan imajinasi mereka dalam pembelajaran kitabah, selain dari pada itu tulisan-tulisan siswa diharapkan akan terlatih lebih baik lagi dan lebih rapi dari pada tulisan-tulisan sebelumnya.

\section{Keunggulan dan Kelemahan}

Setiap media pembelajaran memiliki kelebihan dan kekurangan masing masing. Tidak ada satu media apapun yang dianggap paling baik dan cocok untuk semua jenis materi pembelajaran. Tuntutan bagi guru adalah dapat menguasai aneka ragam media pembelajaran dan dapat menentukan media mana yang cocok untuk digunakan dalam setiap pembelajaran. ${ }^{8}$

Dalam memilih media pembelajaran kemahiran bahasa arab tentunya penting dalam mempertimbangkan keunggulan dan kelemahan media, karena pada dasarnya pembelajaran

${ }^{8}$ Heri Achmadi Dkk, "Penerapan Model Assure dengan Menggunakan Media Power Point dalam Pembelajaran Bahasa Inggris sebagai Usaha Peningkatan Motivasi dan Prestasi Belajar Siswa Kelas X MAN Sukoharjo Tahun Pelajaran 2012/2013”, Jurnal Teknologi Pendidikan dan Pembelajaran, Vol. 2, No. 1, Maret 2014, h. 36. 
akan lebih efektif dan efisien jika guru tahu dan paham bagaimana cara memakai dan pada saat kondisi bagaimana media pembelajaran digunakan, dan juga mempertimbangkan relevan atau tidaknya materi dengan media pembelajaran yang akan digunakan.

Adapun keunggulan dan keutamaan dari media pembelajaran kemahiran berbahasa arab ialah sebagai berikut:

a. Penyajiannya menarik karena ada permainan warna, huruf dan animasi, baik animasi teks maupun animasi gambar atau foto.

b. Lebih merangsang anak untuk mengetahui lebih jauh informasi tentang bahan ajar yang tersaji.

c. Pesan informasi secara visual mudah dipahami peserta didik.

d. Tenaga pendidik tidak perlu banyak menerangkan bahan ajar yang sedang disajikan.

e. Dapat diperbanyak sesuai kebutuhan, dan dapat dipakai secara berulang-uang

f. Dapat disimpan dalam bentuk data optik atau magnetik (CD/Disket /Flashdisk), sehingga paraktis untuk dibawa kemana-mana. ${ }^{9}$

Di sisi lain, suharno mengungkapkan pendapatnya tentang keunggulan dan kelebihan power point sebagai media pembelajaran, dalam hal ini juga bisa digunakan sebagai media pembelajaran kemahiran berbahasa arab. Empat belas keunggulan dan kelebihan tersebut adalah sebagai berikut: ${ }^{10}$

a. Dapat menggabungkan teks dan gambar.

b. Dapat memasukkan hitungan dan tabel sebagai pendukung dari materi kita.

c. Dapat disisipkan gambar atau foto bahkan video dan animasi dari berbagai program ataupun karya sendiri.

d. Mudah disunting atau diedit antara lain menghapus, memindahkan dan menyalin slide, bahkan menyisipkan slide baru.

e. Tampilan slide dapat disesuaikan dengan keinginan kita baik tulisan atau munculnya slide dengan berbagai Untuk menjelaskan struktur organisasi.

f. Untuk memperkenalkan suatu produk.

g. Untuk menjelaskan materi atau program versi.

h. Tidak ada batasan lembar atau slide pada materi yang akan kita tampilkan.

i. Kita dapat memberikan penekanan pada materi yang dianggap lebih penting dengan memberikan warna atau ukuran huruf yang berbeda pada bagian yang kita inginkan.

j. Kita dapat memilih latar belakang slide sesuai dengan materi sehingga peserta didik akan lebih jelas dalam memperhatikan materi.

k. Kita dapat mengulang materi sebelum atau sesudah yang kita terangkan dengan cepat.

1. Dapat ditambahkan system audio sehingga tampilan memberikan informasi dan pengetahuan yang tidak membosankan.

m. Materi yang kita gunakan mempunyai daya simpan yang lama dan dapat kita perbaharui kapanpun.

\footnotetext{
${ }^{9}$ Imam Asrori dan Moh. Ahsanuddin, Media Pembelajaran Bahasa Arab dari Kartu Sederhana sampai Web Penjelajah Dunia, (Malang: Bintang Sejahtera, 2015), h. 180.

${ }^{10}$ Suharno Widi Nugroho, Bermain Lembar Presentasi (Ms. Power Point), (Jakarta: BSD MIPA, 2007), h. 22 .
} 
n. Materi dapat kita gandakan dengan cepat.

Selain dari diatas pendapat diatas, penulis menambahkan bahawa power point juga memiliki keunggulan dan kelebihan, yaitu :

a. Memiliki variasi teknik penyajian sehingga siswa tidak merasa bosan

b. Pengontrolannya mudah dan kapan saja di setiap sesi pembelajaran.

c. Lebih sehat bila dibandingkan dengan media klasik seperti papan tulis.

Sedangkan kekurangan dan kelemahan dari media pembelajaran kemahiran berbahasa arab ialah sebagai berikut :

a. Dibutuhkan biaya tinggi untuk pengadaan perangkat pendukung berupa computer, LCD dan system audio dalam pengoperasiannya.

b. Dibutuhkan kemauan dan kreativitas guru dalam pembuatan media power point sehingga materi yang disajikan terlihat menarik dan professional.

c. Dibutuhkan kemampuan untuk merangkai dan mengoperasikan perangkat dan aplikasi yang berhubungan dengan penyajian materi power point tersebut. ${ }^{11}$

Selain dari penjelasan diatas, penulis melihat bahwa power point juga memiliki kekurangan dan kelemahan lainnya, yaitu :

a. Power Point ini hanya dapat dijalankan/dioperasikan pada satu sistem yaitu operasi Windows.

b. Power Point memiliki ketergantungan arus listrik sangat tinggi.

c. Power Point memiliki kendala bagi guru atau pendidik dengan kemampuan terbatas/cacat/disable.

Dari uraian di atas dapat dicermati bahwa keunggulan dan kelebihannya lebih besar manfaatnya jika pendidik menggunakan media power point dalam proses pembelajaran terlebih dalam era digital sekarang ini. Begitu pula jika dicermati, kekurangan dan kelemahan media power point dalam proses pembelajaran tidak terlalu banyak memberatkan guru dalam penggunaannya, jika fasilitasnya berupa perangkat pendukung seperti computer, LCD dan system audio yang dalam pengoperasiannya dapat disediakan oleh pihak sekolah atau kampus.

\section{Simpulan}

Beberapa point yang dapat disimpulkan dari penjelasan dan uraian tentang "Penggunaan Power Point dalam Pembelajaran Kemahiran Berbahasa Arab" di atas adalah sebagai berikut:

a. Power point merupakan aplikasi presentasi yang memberikan fasilitas menu pilihan untuk memudahkan pelaku dalam mendesain atau merancang apa yang akan dipresentasikan, sehingga presentasi yang disampaikan akan terlihat menarik.

b. Pembelajaran kemahiran berbahasa arab dengan menggunakan media power point dapat meliputi kemahiran istima', kalam, qira'ah dan kitabah.

${ }^{11}$ Budi Setyawan, "Pengaruh Media Power Point terhadap Peningkatan Prestasi Belajar Biologi siswa Kelas IX-G SMP Negeri 39 Surabaya”, E-Jurnal Dinas Pendidikan Kota Surabaya, Vol. 4, 2012, h. 5. 
c. Keunggulan dan kelebihannya lebih besar manfaatnya jika pendidik menggunakan media power point dalam proses pembelajaran dibandingkan dengan kekurangannya karena disamping praktis juga zamannya di era digital.

Sebagai rekomendasi dalam penggunaan media power point agar seorang pendidik pintar dalam penggunaan IT minimal bisa mengoperasikan perangkat komputer. Dan juga kepada pihak stake holder dan madrasah agar menyediakan fasilitas media pembelajaran yang bisa mendukung pembelajaran seorang guru seperti perangkat pendukung berupa computer, LCD dan audio system. ${ }^{[]}$

\section{Daftar Rujukan}

Achmadi, Heri, Dkk., "Penerapan Model Assure dengan Menggunakan Media Power Point dalam Pembelajaran Bahasa Inggris sebagai Usaha Peningkatan Motivasi dan Prestasi Belajar Siswa Kelas X MAN Sukoharjo Tahun Pelajaran 2012/2013”, Jurnal Teknologi Pendidikan dan Pembelajaran, Vol. 2, No. 1, Maret 2014.

Alkash, Kheira Altaher Musa, dan Zamzam Emhemmad Mari Al-Dersi, "Advantages of Using PowerPoint Presentation in EFL Classroom \& the Status of its Use in Sebha University", International Journal of English Language \& Translation Studies, Vol. 1, Issue. 1, Edition, April-June 2013.

Arsyad, Azhar, Media Pembelajaran, Jakarta: PT Raja Grafindo Persada, 2010.

Asrori, Imam, dan Moh. Ahsanuddin, Media Pembelajaran Bahasa Arab dari Kartu Sederhana sampai Web Penjelajah Dunia, Malang: Bintang Sejahtera, 2015.

Daryanto, Media Pembelajaran, Bandung: PT. Sarana Tutorial Nurani Sejahtera, 2012.

Nugroho, Suharno Widi, Bermain Lembar Presentasi (Ms. Power Point), Jakarta: BSD MIPA, 2007.

Nuha, Ulin, Metodologi Super Efektif Pembelajaran Bahasa Arab, Yogyakarta: Diva Press, 2012.

Rahyubi, Heri, Teori-teori Belajar dan Aplikasi Pembelajaran Motorik, Bandung: Nusa Media, 2012.

Rusman, Kurniawan, dan Riyana, Pembelajaran Berbasis Teknologi Informasi dan Komunikasi: Mengembangkan Profesionalitas Guru, Jakarta: PT. Raja Grafindo Persada, 2012.

Setyawan, Budi, "Pengaruh Media Power Point terhadap Peningkatan Prestasi Belajar Biologi siswa Kelas IX-G SMP Negeri 39 Surabaya”, E-Jurnal Dinas Pendidikan Kota Surabaya, Vol. 4, 2012

Suhendi, Edi, Membuat Presentasi Cantik dengan Microsoft Power Point 2007 untuk Pemula, Bandung: Yrama Widya, 2009. 